\title{
URGENCE OF SAINTIFIC-BASED INQUIRY IMPLEMENTATION IN IMPROVING STUDENT'S CRITICAL THINKING ABILITY
}

\section{Devi Afriyuni Yonanda, Yuyun Dwi Haryanti}

Universitas Majalengka

deviyonanda1990@gmail.com

\section{Article History}

accepted 30/09/2018

approved $12 / 10 / 2018$

published 30/10/2018

\section{Keywords}

Inquiry, Scientific, critical thinking

\begin{abstract}
Emphasis on learning in the 2013 Curriculum puts forward the development of knowledge, attitudes and skills of students. The Scientific Approach is believed to be a gold platform to produce quality human resources because the learning process is scientific. As we know in Elementary School learning emphasizes on memorization alone where students must memorize all the material that has been learned.Rote learning is certainly not meaningful for students because students will easily forget what they have learned. The ability that students must possess is one of them is critical thinking.Scientific based inquiry needs to be applied in improving students' critical thinking skills, especially in elementary school.Inquiry-based scientific learning models cultivate scientific thinking skills, developing sense of inquiry and students' creative thinking skills.Through writing about inquiry-based scientific inquiry empirically it can be used as an effort to improve students' critical thinking skills.
\end{abstract}

Social, Humanities, and Education Studies (SHEs): Conference Series https://jurnal.uns.ac.id/shes

p-ISSN 2620-9284 e-ISSN 2620-9292 


\section{PENDAHULUAN}

Namun, sejauh ini pemahaman pentingnya pengembangan kemampuan berpikir kritis belum tersosialisasi secara menyeluruh dalam lingkungan pendidikan. Berdasarkan hasil penelitian yang dikemukakan Frijters et al. diberbagai bidang sosial-sains, dapat diketahui bahwa peserta didik yang lulus dari berbagai sekolah di berbagai negara tidak memiliki kemampuan untuk bersaing pada skala global karena tidak memiliki kemampuan berpikir secara kritis. Hal tersebut pun didukung dengan kenyataan di lapangan yang menunjukkan bahwa proses pembelajaran masih cenderung berpusat pada guru (teacher-center). Dalam pembelajaran siswa dituntut untuk menghafal fakta, konsep, maupun teori terhadap materi yang mereka pelajari. Penghafalan materi meskipun banyak siswa yang mampu menyajikan dengan baik, namun seringkali mereka tidak memahami subtansi materi secara mendalam. Hal ini sejalan dengan pendapat wirtha \& Rapi (2008) bahwa masih banyak siswa belajar hanya menghafal konsep2, mencatat apa yang disampaikan oleh guru, pasif, dan jarang menggunakan pengetahuan awal sebgai dasar perencanaan pembeljaran.Cara tersebut sudah tidak relevan lagi diterapkan karena informasi yang diterima bersifat memori jangka pendek sehingga tidak menimbulkan pembelajaran bermakna bagi siswa.

Sekolah Dasar merupakan sasaran terpenting sebagai awal menumbuhkan kemampuan berpikir. Kemampuan berpikir perlu dilatih sedini mungkin melalui proses belajar selayakanya proses pembelajaran yang sejalan dengan perkembangan zaman dengan membekali siswa yang berorientasi pada aspek kognitif, afektif, dan psikomotor. Pembelajaran yang mencakup ketiga ranah tersebut terdapat dalam pendekatan saintifik. Pendekatan saintifik merupakan pendekatan pembelajaran yang menuntut siswa beraktivitas sebagaimana seorang ahli sains. Dalam praktiknya siswa diharuskan melakukan serangkaian aktivitas selayaknya langkah-langkah penerapan metode ilmiah. Serangkaian aktivitas dimaksud meliputi (1) merumuskan masalah, (2) mengajukan hipotesis, (3) mengumpulkan data, (4) mengolah dan menganalisis data, dan (5) membuat kesimpulan.

Permendikbud Nomor 81 A Tahun 2013 lampiran IV, proses pembelajaran terdiri atas lima pengalaman belajar pokok yaitu: (1) mengamati mengutamakan kebermaknaan proses pembelajaran (meaningfull learning). Metode ini memiliki keunggulan tertentu, seperti menyajikan media obyek secara nyata, peserta didik senang dan tertantang, dan mudah pelaksanaannya. Metode mengamati sangat bermanfaat bagi pemenuhan rasa ingin tahu peserta didik. Sehingga proses pembelajaran memiliki kebermaknaan yang tinggi. (2) bertanya mengenai apa yang sudah dilihat, disimak, dibaca atau dilihat. Adapun kompetensi yang diharapkan dalam kegiatan ini adalah mengembangkan kreativitas, rasa ingin tahu, kemampuan merumuskan pertanyaan untuk membentuk pikiran kritis yang perlu untuk hidup cerdas dan belajar sepanjang hayat. (3) Kegiatan ini dilakukan dengan menggali dan mengumpulkan informasi dari berbagai sumber melalui berbagai cara. Untuk itu peserta didik dapat membaca buku yang lebih banyak, memperhatikan fenomena atau objek yang lebih teliti, atau bahkan melakukan eksperimen. Dari kegiatan tersebut terkumpul sejumlah informasi. (4) mengolah informasi, kegiatan "mengasosiasi/ mengolah informasi/ menalar" yang bersifat menambah keluasan dan kedalaman sampai kepada pengolahan informasi yang bersifat mencari solusi dari berbagai sumber yang memiliki pendapat yang berbeda sampai kepada yang bertentangan. Kegiatan ini dilakukan untuk menemukan keterkaitan satu informasi dengan informasi lainya, (5) Mengkomunikasikan apa yang telah mereka pelajari. Kegiatan ini dapat dilakukan melalui menuliskan atau menceritakan apa yang ditemukan dalam kegiatan mencari informasi, mengasosiasikan dan menemukan pola. Hasil tersebut disampikan di kelas dan dinilai oleh guru sebagai hasil belajar peserta didik atau kelompok peserta didik tersebut 
Berdasarkan hasil kajian yang muncul dalam proses belajar mengajar, perlu ada perubahan orientasi guru dalam mengemas sistem pembelajaran. Penggunaan model, bahan ajar serta media pembelajaran menjadi sarana penting demi terwujudnya pembelajaran yang aktif, kreatif, efektif, inovatif, menyenangkan, dan bermakna. Proses pembelajaran memerlukan bimbingan, arahan serta motivasi guru sangat penting dan mempunyai manfaat yang besar sehingga mampu menciptakan pembelajaran yang meningkatkan kemampuan berpikir kritis siswa. Hal ini sesuai pendapat Forum Mangun wijaya (2013) menyebutkan bahwa Pendidikan perlu menumbuhkan budaya menalar secara saintifik sejak dini. Kemampuan seperti itulah apabila dibina dan dilatih dengan baik maka dapat menumbuh kembangkan kesadaran berpikir kritis.

Implementasi inquiry berbasis saintifik diharapkan menjadi salah satu alternatif dalam menciptakan pembelajaran bermakna sehingga dapat meningkatkan kemampuan berpikir kritis siswa. Model inquiry sebagai model pembelajaran yang meliputi kegiatan sosial dan kegiatan ilmiah dalam menyelesaikan masalah. Kegiatan sosial dimana siswa berdiskusi dan bekerjasama dengan temannya untuk menyelesaiakan masalah. Kegiatan ilmiah dilakukan siswa dalam melakukan penyelidikan terhadap suatu masalah untuk dipecahkan. Keterampilan berpikir siswa akan terbentuk melalui langkah-langkah sistematis dalam menyelesaikan masalah yang mencakup: penetapan hipotesis, memilih metode yang sesuai untuk menyelidiki fenomena tertentu, menemukan hasil dan menyimpulkan. Suchman (Joyce, et al., 2009) mengemukakan bahwa tujuan model inkuiri ialah "mengembangkan keterampilan kognitif dalam melacak dan mengolah data-data. Disamping itu model ini ditujukan untuk meningkatkan kemampuan siswa dalam melihat konsep-konsep logis serta hubungan kualitas dalam mengolah sendiri informasi secara produktif". Model pembelajaran inquiry berbasis Saintifik akan memberikan pengalaman belajar kepada siswa karena dalam proses pembelajaran meliputi kegiatan mengamati, menanya, menalar, mencoba, dan mengkomunikasikan. Proses pembelajaran seperti itulah tidak hanya berdampak pada aspek kognitif melainkan pada aspek afektif dan psikomotor siswa. Pengembangan model inquiry berbasis saintifik digunakan dalam pembelajaran sehingga dapat mengarahkan siswa untuk berfikir kritis. Siswa yang memiliki keterampilan berfikir kritis dapat dijadikan penalaran sebagai landasan berfikir, berani megambil keputusan dan konsisten dengan keputusan tersebut.

Bertenali dengan penjelasan di atas penulis tertarik untuk membahas lebih lanjut pentingnya implementasi inquiry berbasis saintifik dalam meningkatkan kemampuan berpikir kritis siswa. Tujuan utama dari tulisan ini adalah mendeskripsikan implementasi inquiry berbasis saintifik menningkatkan kemampuan berpikir kristis siswa di sekolah dasar. Kajian ini merupakan kajian konseptual menggunakan studi literatur yang bersumber dari jurnal-jurnal terkait dengan kajian tersebut.

\section{PEMBAHASAN}

Model pembelajaran inkuiri merupakan rangkaian kegiatan belajar yang melibatkan seluruh kemampuan siswa untuk mencari dan menyelidiki secara sistematis, kritis, logis, dan analitis, sehingga siswa dapat merumuskan sendiri penemuannya dengan penuh percaya diri. Seperti halnya yang dikatakan oleh Gulo (dalam Trianto: 2010) "inkuiri berarti suatu rangkaian kegiatan belajar yang melibatkan secara maksimal seluruh kemampuan siswa untuk mencari dan menyelidiki secara sistematis, kritis, logis, analitis sehingga mereka dapat merumuskan sendiri penemuanya dengan penuh percaya diri". Sejalan dengan pendapatnya Gulo, Sanjaya pun mengemukakan hal serupa menurut Sanjaya (2014) "inkuiri adalah rangkaian kegitan pembelajaran yang menekankan pada proses berpikir secara kritis dan analitis 
untuk mencari dan menemukan jawaban sendiri dari suatu masalah yang dipertanyakan".

Pembelajaran inkuiri mempunyai tiga karakteristik, diantaranya:

1. Pembelajaran inkuiri menekankan kepada aktivitas siswa secara maksimal untuk mencari dan menemukan

2. Seluruh aktivitas yang dilakukan siswa diarahkan untuk mencari dan menemukan sendiri jawaban dari sesuatu yang dipertanyakan, sehingga diharapkan dapat menumbuhkan sikap percaya diri (self belief).

3. Tujuan dari penggunaan strategi inkuiri dalam pembelajaran adalah mengembangkan kemampuan berpikir secara sistematis, logis, dan kritis, atau mengembangkan kemampuan intelektual sebagai bagian dari proses mental.

Adapun keunggulan dalam mengimplementsikan model inkuiri dalam pembelajaran adalah sebagai berikut:

1. Menekankan pada pengembangan aspek kognitif, afektif, dan psikomotorik secara seimbang.

2. Siswa menjadi aktif dalam mencari dan mengolah sendiri informasi.

3. Siswa mengerti konsep-konsep dasar dan ide-ide secara lebih baik.

4. Memberikan ruang kepada siswa untuk belajar sesuai dengan gaya belajar mereka.

5. Siswa yang memiliki kemampuan diatas rata-rata tidak akan terhambat oleh siswa yang lemah dalam belajar.

6. Membantu siswa dalam menggunakan ingatan dalam transfer konsep yang dimilikinya kepada situasi-situasi proses belajar yang baru.

7. Mendorong siswa untuk berfikir intuitif dan merumuskan hipotesisnya sendiri.

8. Dapat membentuk dan mengembangkan konsep sendiri (self-concept) pada diri siswa sehingga secara psikologis siswa lebih terbuka terhadap pengalaman baru, berkeinginan untuk selalu mengambil dan mengeksploitasi kesempatankesempatan yang ada.

9. Memungkinkan siswa belajar dengan memanfaatkan berbagai jenis sumber yang tidak hanya menjadikan guru sebagai satu-satunya sumber balajar.

Pendekatan saintifik merupakan pendekatan pembelajaran yang menuntut siswa beraktivitas sebagaimana seorang ahli sains. Dalam praktiknya siswa diharuskan melakukan serangkaian aktivitas selayaknya langkah-langkah penerapan metode ilmiah. Serangkaian aktivitas dimaksud meliputi (a) merumuskan masalah, (b) mengajukan hipotesis, (c) mengumpulkan data, (d) mengolah dan menganalisis data, dan (e) membuat kesimpulan. Abidin (2013:45). Dalam pembelajaran, pendekatan saintifik dapat diartikan sebagai pendekatan pembelajaran yang dikembangkan dengan berdasarkan pada pendekatan ilmiah. Menurut Permendikbud Nomor $81 \mathrm{~A}$ Tahun 2013 lampiran IV, dalam konsep pendekatan ilmiah proses pembelajaran terdiri atas lima pengalaman belajar pokok yaitu:

a. mengamati;

b. menanya;

c. Mengumpulkan informasi/eksperimen;

d. Mengasosiasikan/mengolah informasi; dan

e. Mengkomunikasikan.

Berdasarkan pemaparan di atas, dapat diambil kesimpulan bahwa model inkuiri berbasis saintifik adalah kegiatan belajar yang melibatkan seluruh kemampuan siswa untuk mencari dan menyelidiki secara sistematis, kritis, logis, analitis melalui kegiatan yang meliputi merumuskan masalah, mengajukan hipotesis, mengumpulkan data, 
mengolah dan menganalisis data, serta membuat kesimpulan sehingga siswa dapat merumuskan sendiri penemuannya dengan penuh percaya diri. Dalam prosesnya, adapun langkah-langkah atau sintak model Inquiry Berbasis Saintifik (IBS) yaitu sebagai berikut: (1) tahap orientasi, (2) tahap merumuskan masalah, (3) tahap merumuskan hipotesis, (4) tahap mengumpulkan data, (5) tahap menguji hipotesis, (6) tahap merumuskan kesimpulan, dan (7) tahap strategi dan taktik.

Berpikir kritis merupakan salah satu dari beberapa keterampilan inovasi yang sangat penting dikembangkan pada anak sejak dini. Black (Hughes, 2014: 33) mendefinisikan berpikir kritis sebagai berpikir nalitis yang berdasarkan wacanara sional dengan penyelidikan serta pendekatan teliti dan ketat. Ennis (Çimer, 2013) juga menyatakan bahwa berpikir kritis didefinisikan sebagai aktivitas disiplin mental untuk berfikir reflektif dan masuk akal untuk mengevaluasi argumen atau proposisi dalam mengambil keputusan apa yang harus dipercaya atau dilakukan. Kemudian Sternberg (Lai:2011) menyatakan "Critical thinking is the mental processes, strategies, and representations people use to solve problems, make decisions, and learn new concepts", yang dapat diartikan bahwa berpikir kritis adalah proses mental, stategi, dan representasi yang digunakan orang untuk memecahkan masalah, membuat keputusan, dan mempelajari konsep-konsep baru.

Dengan demikian, berdasarkan beberapa pendapat para ahli mengenai definisi berpikir kritis maka dapat disimpulkan bahwa berpikir kritis merupakan aktivitas terampil dan disiplin mental untuk berfikir reflektif dan masuk akal dalam mengevaluasi argumen, memecahkan masalah, mengambil keputusan, membujuk, menganalisis asumsi, melakukan penelitian ilmiah serta dalam mempelajari konsep-konsep baru. Berpikir kritis sangat penting dimiliki siswa untuk belajar sehingga memiliki kemampuan dalam memecahkan masalah, penyelidikan dan penemuan. Proses pembelajaran inilah akan membuat siswa terampil memecahkan permasalahan yang dihadapi siswa. Hal ini sesuai yang diungkapkan Dewey, "Critical thinkingis the most important skill for problem solving, inquiry and discovery. It is the systematic approach of skil fully evaluating information to arrive atthemostfeasible solutionoal variety of structured and ill-structured problems" (Laxman, 2010;).

Menurut Ennis (2011) indikator kemampuan berpikir kritis dapat dikelompokkan dalam 5 (lima) indikator, yaitu : (a) memberikan penjelasan sederhana (elementary clarification), (b) membangun keterampilan dasar (basic support), (c) menyimpulkan (interence), (d) membuat penjelasan lebih lanjut (advanced clarification), dan (e) strategi dan taktik (strategies tactics)Pada dasarnya, berpikir kritis tidak bisa diperoleh dalam waktu singkat tanpa latihan atau pembiasaan. Sihotang dkk. (2012) Menjelaskan bahwa dalam mengembangkan kemampuan berpikir kritis terdapat beberapa langkah yang perlu dilakukan, yaitu sebagai berikut:

1) Mengenali masalah

2) Menemukan cara-cara yang dapat dipakai untuk menangani masalah

3) Mengumpulkan dan menyusun informasi yang diperlukan untuk menyelesaikan masalah

4) Mengenal asumsi-asumsi dan nilai-nilai yang tidak dinyatakan

5) Menggunakan bahasa yang tepat, jelas, dan khas dalam membicarakan suatu persoalan atau suatu hal yang diterimanya.

6) Mengevaluasi data dan menilai fakta serta pernyataan-pernyataan

7) Mencermati adanya hubungan logis antara masalah-masalah dengan jawabanjawaban yang diberikan. 
8) Menarik kesimpulan-kesimpulan atau pendapat tentang isu atau persoalan yang sedang dibicarakan.

Berdasarkan pemaparan diatas, maka dapat ditarik kesimpulan bahwa pembelajaran inkuiry berbasis saintifik merupakan strategi yang cocok untuk mengembangkan berpikir kritis siswa. Dengan menggunakan kemampuan berpikir secara kritis dan analitis siswa dapat mengeksplor pengetahuan dan melakukan penyelidikan secara logis dan mengolah informasi yang didapatnya sesuai dengan kemampuan yang dimiliki terhadap merumuskan penemuanya dengan penuh rasa percara diri.

\section{SIMPULAN}

Model pembelajaran inquiry merupakan rangkaian kegiatan belajar yang melibatkan seluruh kemampuan siswa untuk mencari dan menyelidiki secara sistematis, kritis, logis, dan analitis, sehingga siswa dapat merumuskan sendiri penemuannya dengan penuh percaya diri. Sedangkan pendekatan saintifik merupakan pendekatan pembelajaran yang menuntut siswa beraktivitas sebagaimana seorang ahli sains. Dimana dalam praktiknya siswa diharuskan melakukan serangkaian aktivitas selayaknya langkah-langkah penerapan metode ilmiah.

Pada abad ke-21, dimana era digital yang serba modern, berpikir kritis merupakan salah satu dari beberapa keterampilan inovasi yang dibutuhkan untuk mempersiapkan lulusan yang dapat bersaing dalam mengisi pasar kerja, sehingga memunculkan sebuah keharusan dalam melatih dan mengembangkan kemampuan berpikir kritis siswa. Sejalan dengan hal tersebut, Ennis (Çimer, 2013) menyatakan bahwa berpikir kritis didefinisikan sebagai aktivitas disiplin mental untuk berfikir reflektif dan masuk akal untuk mengevaluasi argumen atau proposisi dalam mengambil keputusan apa yang harus dipercaya atau dilakukan.

Dengan demikian, pembelajaran inquiry berbasis saintifik merupakan model yang cocok untuk mengembangkan kemampuan berpikir kritis siswa. Dengan menggunakan kemampuan berpikir secara kritis dan analitis siswa dapat mengeksplor pengetahuan dan melakukan penyelidikan secara logis dan mengolah informasi yang didapatnya sesuai dengan kemampuan yang dimiliki terhadap merumuskan penemuanya dengan penuh rasa percara diri.

\section{DAFTAR PUSTAKA}

Abidin, Y. 2013. Pembelajaran bahasa berbasis pendidikan karakter. Bandung: Refika Aditama

Çimer A., Melih T., \& Mehmet K. 2013. Critical thinking level of biology classroom survey: Ctlobics. The Online Journal of New Horizons in Education, 3(1), pg. 1524

Ennis, R.H. 2011. The Nature of Critical Thinking: An Outline of Critical Thinking Dispositions and Abilities. University of Illinois. Diakses dari: http://www.faculty.education.illinois.edu/rhennis/document/TheNatureofCriticalThi nking51711 000.pdf

Forum Magun wijaya. 2013. Menyambut Kurikulum 2013. Jakarta: Buku Kompas

Frijters, S., Geert ten D., \& Gert R. 2008. "Effects of Dialogic Learning on ValueLoaded Critical Thinking". Elsever Learning and Instruction, 18, pp 66-88, DOI: 10.1016

Hughes, C. (2014). Theory of Knowledge aims, objectives and assessment criteria: An analysis of critical thinking descriptors. Journal of Research in International Education 2014, Vol. 13(1) 30: sagepub.co.uk/journalsPermissions.nav. 
Joyce, B. 2009.Marsha Well, andEmilyCalhoun.ModelsofTeachingEightEdition.New Jersey:Pearson Education.

Laxman, K. 2010. A conceptual framework mapping the application of informationsearchstrategiestoselland ill-structuredproblem-solving. Computers\&Education,55(2), 513-526.

Lestari, KE. 2014. "Implementasi brain-based learning untuk meningkatkan kemampuan koneksi dan kemampuan berpikir kritis serta motivasi belajar siswa smp". [jurnal pendidikan unsika] ISSN 2338-2996. Pendidikan Matematika-FKIP UNSIKA

Redhana, I.W dan Liliasari. 2008. program pembelajaran keterampilan berpikir kritis pada topic laju reaksi untuk siswa SMA". jurnal forum kependidikan. Hal 103-112

Sanjaya, W. 2014. Strategi Pembelajaran. Jakarta: Kencana

Sihotang, K., dkk. (2012). Critical thinking, membangun pemikiran logis. Jakarta: Pustaka Sinar Harapan.

Trianto. 2010. Mendesain Model Pembelajaran Inovatif - Progesif. Jakarta: Kencana.

Wirtha, I. M. \& Rapi N.K.2008. pengaruh model pembeljaran dan penalaran formal terhadap penguasaan konsep fisika dan sikap ilmiah siswa sma negeri 4 singaraja:. jurnal penelitian dan pengembangan pendidikan lembaga penelitian Undiksha, 1(2), 15-29. 